\title{
Lifetime Assessment of a Steam Pipeline
}

\author{
Jiří Janovec $^{1}$, Daniela Poláchová ${ }^{1}$, Michal Junek $^{1}$ \\ ${ }^{1}$ CTU in Prague, Faculty of Mechanical Engineering, Department of Materials Engineering, \\ Karlovo náměstí 13, 12135 Prague 2, Czech Republic
}

Correspondence to: Jiri.Janovec@fs.cvut.cz

\begin{abstract}
The aim of this paper is to design a method for assessing the life of steam pipes for Czech power plants. The most widely-used material in Czech power plants is steel 15 128. Our findings may also be applied for international equivalents of this steel. The paper shows the classification of cavitation damage and microstructure classification status, based on the German VGB Act, with references to EPRI law in the USA. Calculations of remaining life on the basis of Russian experience are also shown. The possibility of applying this method to increase the operating parameters for power plants is discussed.
\end{abstract}

Keywords: life assessment of a steam pipeline, creep damage, assessment of microstructure damage.

\section{Introduction}

A switchover to high-parametric power plants requires an assessment of the remaining life of existing steam piping. In creep conditions, this requires a large amount of information on operating conditions (temperature, pressure, time), material characteristics (microstructure, creep strength, creep strain rate, etc.) It is also important to monitor the stress in exposed parts and weld joints. The greatest influence on component life is the formation and joining of internal defects, i.e. cavities. It is therefore necessary to provide a sophisticated method for observing and evaluating internal defects. This paper deals mainly with steel type 15128 , because the vast majority of the steam piping currently operating in the Czech Republic is made from this material.

\section{Material 15128 (14MOV6-3)}

This is a low-alloy heat-resistant $\mathrm{CrMoV}$ steel with guaranteed weldability. The main use of this steel is for steam piping, superheaters and boiler tubes operating at temperatures up to $580{ }^{\circ} \mathrm{C}$.

The microstructure of steel in the initial state depends on the heat treatment that it has undergone. The initial state of 15128.5 has a ferritic-bainitic microstructure with fine dispersion of globular carbides of $\mathrm{M}_{4} \mathrm{C}_{3}$ or $\mathrm{MC}$ type, respectively, precipitated in the ferritic matrix. The initial state of 15128.9 is formed by a fine carbide-bainitic microstructure. The two initial states differ in their mechanical properties; see Table $3[1]$.

Table 1: Equivalent materials according to international standards

\begin{tabular}{|c|c|c|c|c|}
\hline \multirow{2}{*}{ CSN } & \multicolumn{2}{|c|}{ DIN } & \multirow{2}{*}{ GOST } & \multirow{2}{*}{ ASTM } \\
\cline { 2 - 3 } & W. nr. & marking & & \\
\hline 15128 & 1.7715 & $14 \mathrm{MoV} 6-3$ & 12 Ch1MF & Gr. P24 \\
\hline
\end{tabular}

Table 2: Chemical composition of the material according to the standard

\begin{tabular}{|c|c|c|c|c|c|c|c|c|c|}
\hline \multirow{2}{*}{$\begin{array}{c}\text { Identification } \\
\text { according } \\
\text { to CSN }\end{array}$} & \multicolumn{7}{|c|}{ Chemical composition [weight \%] } \\
\cline { 2 - 10 } & $\mathrm{C}$ & $\mathrm{Mn}$ & $\mathrm{Si}$ & $\mathrm{Cr}$ & $\mathrm{Mo}$ & $\mathrm{V}$ & $\mathrm{P}$ & $\mathrm{S}$ & $\mathrm{Al}$ \\
\hline \multirow{2}{*}{15128} & 0.10 & 0.45 & 0.15 & 0.50 & 0.40 & 0.22 & max. & max. & max. \\
& 0.18 & 0.70 & 0.40 & 0.75 & 0.60 & 0.35 & 0.040 & 0.040 & 0.025 \\
\hline
\end{tabular}


Table 3: Mechanical properties of steel 15128 in dependence on heat treatment

\begin{tabular}{|c|c|c|c|c|c|c|c|c|c|c|}
\hline \multirow{2}{*}{$\begin{array}{c}\text { State } \\
*)\end{array}$} & \multirow{2}{*}{$\begin{array}{c}R_{m} \\
{[\mathrm{MPa}]}\end{array}$} & \multirow{2}{*}{$\begin{array}{c}R_{p 0,2} \\
{[\mathrm{MPa}]}\end{array}$} & \multirow{2}{*}{$\begin{array}{l}A_{5} \\
{[\%]}\end{array}$} & \multirow[t]{2}{*}{$\mathrm{HB}$} & \multicolumn{3}{|c|}{$R_{m T} / 10^{5}$ hrs $[\mathrm{MPa}]$} & \multicolumn{3}{|c|}{$R_{m T} / 2.5 \cdot 10^{5} \mathrm{hrs}[\mathrm{MPa}]$} \\
\hline & & & & & $550^{\circ} \mathrm{C}$ & $575^{\circ} \mathrm{C}$ & $600^{\circ} \mathrm{C}$ & $550^{\circ} \mathrm{C}$ & $575^{\circ} \mathrm{C}$ & $600^{\circ} \mathrm{C}$ \\
\hline .5 & $\begin{array}{l}490 \\
690\end{array}$ & $\begin{array}{c}\min . \\
365\end{array}$ & $\begin{array}{c}\min . \\
18\end{array}$ & $\begin{array}{l}140 \\
197\end{array}$ & 89 & 64 & 45 & 73 & 51 & 35 \\
\hline .9 & $\begin{array}{l}570 \\
740\end{array}$ & $\begin{array}{c}\min . \\
430\end{array}$ & $\begin{array}{c}\min . \\
17\end{array}$ & $\begin{array}{l}163 \\
223\end{array}$ & 107 & 75 & $(51)$ & 88 & 59 & $(38)$ \\
\hline
\end{tabular}

*) $15128.5-960{ }^{\circ} \mathrm{C} / 30 \mathrm{~min} /$ air $+710^{\circ} \mathrm{C} / 1$ hour/air

$15128.9-970{ }^{\circ} \mathrm{C} / 30 \mathrm{~min} /$ water $+720^{\circ} \mathrm{C} / 1$ hour/air

Table 4: Summary of tests for steam piping [2]

\begin{tabular}{|c|c|c|c|c|}
\hline Type of samples & \multicolumn{2}{|c|}{ Test methodology } & \multicolumn{2}{|c|}{ Obtained data } \\
\hline \multirow{4}{*}{$\begin{array}{l}\text { Pipeline } \\
\text { (non-destructive } \\
\text { tests) }\end{array}$} & Replicas & Visual tests & Cavity formation & Cracking \\
\hline & $\begin{array}{l}\text { Ultrasonic } \\
\text { methods }\end{array}$ & Hardness testing & $\begin{array}{l}\text { Density of } \\
\text { inclusions }\end{array}$ & Spheroidization \\
\hline & Penetration test & Mag. powder test & $\begin{array}{l}\text { Segregation of } \\
\text { sulphides }\end{array}$ & Hardness \\
\hline & $\begin{array}{l}\text { Optical fibre } \\
\text { measurement }\end{array}$ & Chemical analysis & $\begin{array}{l}\text { Size and type of } \\
\text { grain }\end{array}$ & \\
\hline \multirow{4}{*}{$\begin{array}{l}\text { Metallographical } \\
\text { samples } \\
\text { (destructive tests) }\end{array}$} & Replicas & Hardness testing & $\begin{array}{l}\text { Fusion line } \\
\text { cracking }\end{array}$ & Cavities formation \\
\hline & Light microscopy & $\begin{array}{l}\text { Electron } \\
\text { microscopy }\end{array}$ & Hardness & Spheroidization \\
\hline & Cryo-cracking & $\begin{array}{l}\text { Cross-weld stress } \\
\text { rupture test }\end{array}$ & $\begin{array}{l}\text { Fine-grain HAZ } \\
\text { damage }\end{array}$ & $\begin{array}{l}\text { Damage to weld } \\
\text { metal }\end{array}$ \\
\hline & & & $\begin{array}{l}\text { Density of } \\
\text { inclusions }\end{array}$ & $\begin{array}{l}\text { Size and type of } \\
\text { grain }\end{array}$ \\
\hline
\end{tabular}

\section{Monitoring the operating parameters, service life management}

The main parameters that should be monitored over time are the temperature and the pressure of steam in the steam pipeline. Regular monitoring of the operating parameters several times a year is most advantageous in terms of creep lifetime.

\subsection{According to epri (USA) [2]}

A three-stage approach is used for evaluating the lifetime of steam pipelines. At each stage, the estimated remaining life and the desired service life of the steam pipeline are compared.

STAGE 1: Includes general calculations based on operating history and especially exploring the pos- sibility of degradation of components. The main contents of this stage are the relevant technical drawings, material properties, operating hours and cycles, history of inspections and maintenance, failure history (details of failures and repairs to failures), operational parameters and their maximum values (temperature and pressure).

STAGE 2: Includes non-destructive testing of components, the results of which can improve the evaluation of the lifetime in STAGE 1. For tests carried out at this stage, see Table 4 . Visual examination includes observation of geometric inaccuracies (e.g. buckling). This includes geometry measurements (wall thickness, ovality) and measurements of the position of selected hinges and supports. If cracks are found by capillary tests, an ultrasonic examination is to be made. The replica method provides a preliminary estimate of the lifetime of the steam piping (welded joints). 


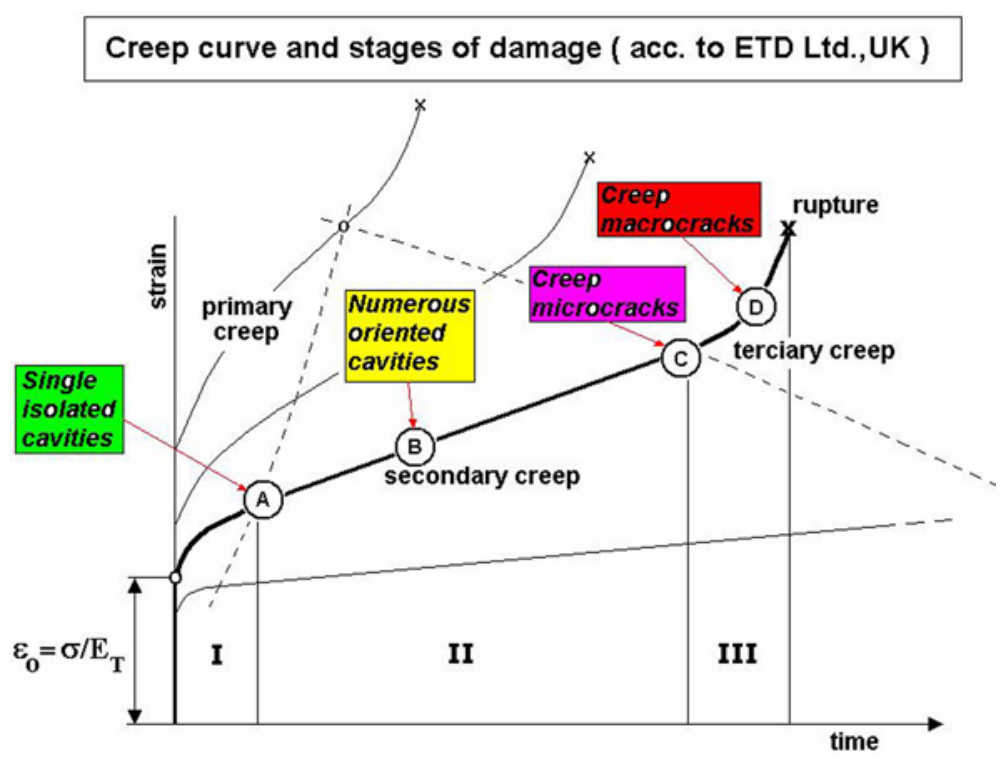

Figure 1: Creep curve with states of cavitation damage marked on it [3]

STAGE 3: Includes destructive testing and detailed analysis of the samples. It is necessary to interrupt the operation and remove a part of the steam pipeline. This stage provides the most accurate estimate of the remaining life of the samples. The observed data is compared with the data determined in STAGE 2. The tests are presented in Table 4. The high cost of this type of evaluation needs to be taken into account. (For example, is it better to replace or repair a part of the steam piping, or is it better to operate under lower conditions?)

According to [3], the replica method can be used on properly prepared surfaces. Two to three replicas should be taken from each site. Microstructure and cavitation (creep) damage is evaluated on the basis of an evaluation of the replicas. Figure 1 shows a creep curve with states of cavitation damage marked on it. The structural condition is assessed according to the etalons. Resistance to corrosion attack can also be assessed with the use of electrochemical polarization measurements.

\subsection{Russian approach (material 12CH1MF)}

\subsubsection{Operation and inspection}

On the straight parts of steam pipelines operating at temperatures from 450 to $545^{\circ} \mathrm{C}$ it is necessary to measure the residual deformation 200 thousand hours after the pipeline came into operation. For steam pipelines operating at temperatures from 546 to $570{ }^{\circ} \mathrm{C}$, analogous measurements should be performed after 150 thousand hours. If the residual de- formation exceeds $0.75 \%$, an assessment of the material is made in terms of mechanical properties and chemical composition.

On the bent parts of the steam piping, measurements of the residual deformation, magnetic powder and ultrasonic flaw detection must be performed after 150 thousand hours. In operating temperature ranges from 546 to $570{ }^{\circ} \mathrm{C}$, this measurement is performed after 100 thousand hours.

For welded joints, the degree of fatigue life $\tau_{h o} / \tau_{l p}$ is evaluated in accordance with the range of structures and their microdamange for welded joints $\left(\tau_{h o}-\right.$ hours of operation; $\tau_{l s}$ - limit service life at the stage of microcrack discovery). The residual service life $\left(\tau_{r s}\right)$ can be calculated from the difference $\tau_{r s}=\tau_{l s}-\tau_{h o}$ [4]. Typical damaged places of welded joints in the creep region are found mainly along the outside of the heat-affected zone of the material.

\subsubsection{Service life calculation}

The lifetime of a steam pipeline operated in the creep region is assessed according to the degree of microdamage within the structure of the material. The basic parameter for calculating the lifetime is the number of micropores in a unit area of the metallographic scratch pattern (replica). Figure 2 shows an example of data processing for steel $12 \mathrm{Ch} 1 \mathrm{MF}$ at $600{ }^{\circ} \mathrm{C}$. For a reliable extrapolation of long-term strength at $100000 \mathrm{hrs}$, it is necessary to start from an experiment planned for at least 4000-5000 hrs. In [5], the calculation was based on 50-300 thousand hrs in creep conditions, steam piping energy blocks 250-800 MW at $515-560^{\circ} \mathrm{C}$ and 3.7 to $25.5 \mathrm{MPa}$. 


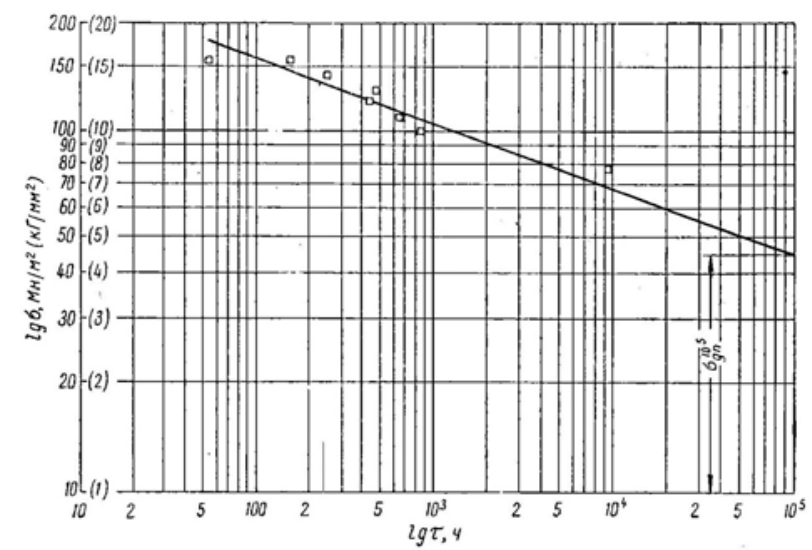

Figure 2: Example of experimental data processing in double logarithmic coordinates after tests on steel $12 \mathrm{Ch} 1 \mathrm{MF}$ for term strength at $600{ }^{\circ} \mathrm{C}[6]$

\subsubsection{Creep time}

The creep time from pore creation to the development of a macro-crack for $12 \mathrm{Ch} 1 \mathrm{MF}$ can be one half of the total operating time, which is $(1-3) \times 10^{5} \mathrm{hrs}$ (in the course of a year the plant works for $(7-8) \times$ $\left.10^{3} \mathrm{hrs}\right)$. Information on the degree of harmfulness of the metal therefore allows the uptime capacity to be calculated. At the present time, the diagnostics is carried out mostly by metallographic methods when the energy blocks are shut down, or during an overhaul. The high work difficulty involved in preparing the metallographic sample reduces the control performance, and extensive repairs are needed. It is therefore necessary to introduce more progressive express methods.

\section{Increasing the operating parameters}

The Russian literature [4,7], presents examples of service life extension by up to an additional 100 thousand hours after appropriate repairs to the welds on the basis of microstructure analysis and degree of damage. Cyclic heat treatment (3 to 10 cycles) with heating up to $980^{\circ} \mathrm{C}$ and cooling effectively regenerates the operating characteristics if the material damage does not exceed $10-15 \%$ in relation to the original state, when $\Delta \rho / \rho \leq 0.1-0.2 \%[?]$. For $12 \mathrm{Ch} 1 \mathrm{MF}$ steel with $0.13 \%$ damage just $2-3$ cycles; at $0.5 \%$ damage, $4-6$ cycles; $1 \%$ (total damage state), 8-10 cycles.

Other specific cases for increasing the operational parameters are very difficult to access. Most of the results and experience gained in relation to this issue are covered by trade secrecy. However, it is obvious that even a small change in operating parameters (e.g. a temperature increase) has a significantly negative effect on the residual service life.

\section{Assessment of microstructure damage}

In our proposal for the metallographic evaluation of a structure, we utilize the classification degrees used by Neubauer, ISQ, and VGB Nordtest, a detailed description of which, and a comparison, are given in Table 5 [3]. Figure 3 shows various states of material 14MoV6-3 damage.

Table 5: Microstructure rating class [3]

\begin{tabular}{|c|c|c|c|c|c|}
\hline $\begin{array}{l}\text { Nordtest } \\
\text { NT } \\
\text { NDT010 }\end{array}$ & $\begin{array}{c}\text { VGB } \\
\text { TW507 }\end{array}$ & $\begin{array}{c}\text { Neuber } \\
\text { and } \\
\text { Waddel }\end{array}$ & Description & Recommendation (Nordtest) & $\begin{array}{c}\text { Consumed } \\
\text { Life-Fraction } \\
(\text { EPRI })\end{array}$ \\
\hline & 0 & & As-received & & \\
\hline 1 & 1 & & No creep cavitation & None & $0-0.14$ \\
\hline \multirow[t]{3}{*}{2} & & $\mathrm{~A}$ & Single cavities & Re-examine after $20000 \mathrm{hrs}$ & $0.05-0.47$ \\
\hline & $2 \mathrm{a}$ & & Isolated cavities & & \\
\hline & $2 \mathrm{~b}$ & & $\begin{array}{l}\text { Numerous cavities, no } \\
\text { preferred orientation }\end{array}$ & & \\
\hline \multirow[t]{3}{*}{3} & & & Coherent cavities & Re-examine after $15000 \mathrm{hrs}$ & \\
\hline & $3 a$ & $\mathrm{~B}$ & Numerous oriented cavities & & $0.27-0.53$ \\
\hline & $3 \mathrm{~b}$ & & Chain of cavities & & \\
\hline 4 & 4 & $\mathrm{C}$ & Creep cracks (micro) & Re-examine after $10000 \mathrm{hrs}$ & $0.29-0.84$ \\
\hline 5 & 5 & $\mathrm{D}$ & Creep macrocracks & Issue immediate warning & $0.7-1.0$ \\
\hline
\end{tabular}




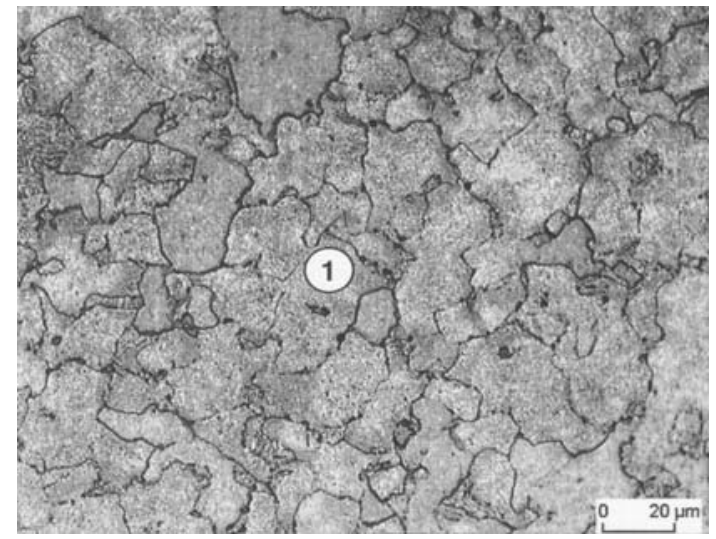

Assessment class 1: No creep cavitation

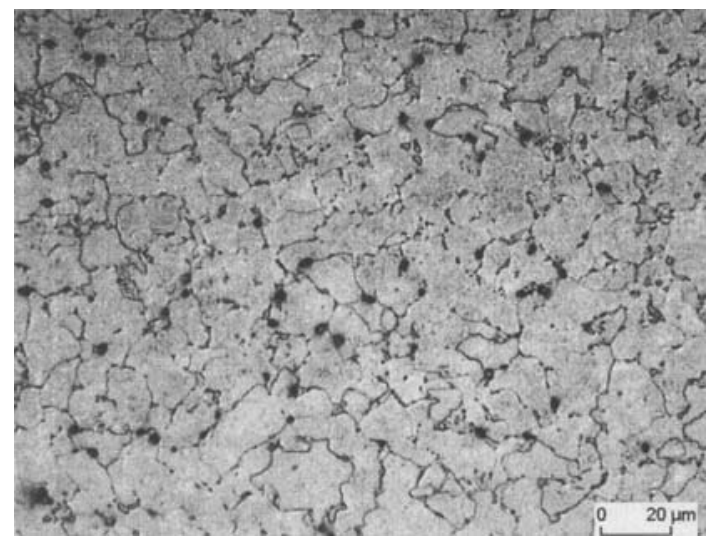

Assessment class 2b: Numerous cavities

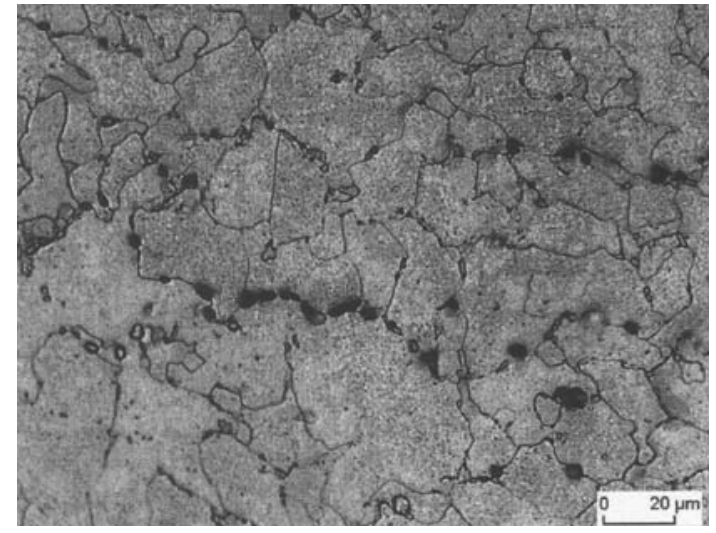

Assessment class 3b: Chain of cavities

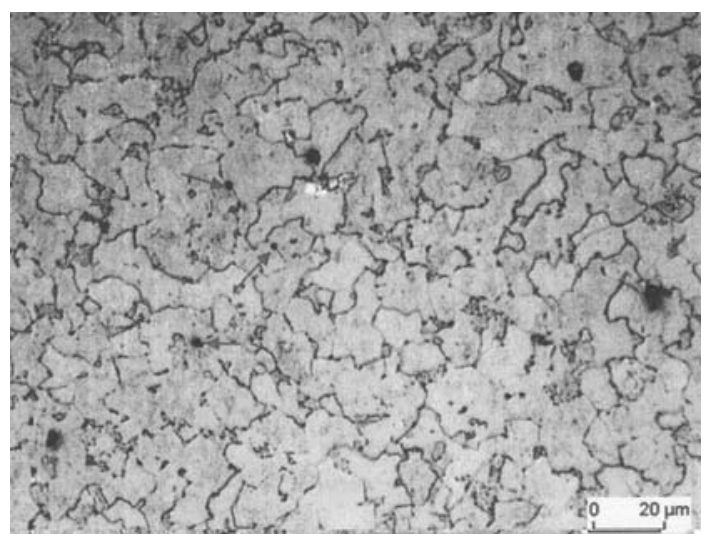

Assessment class 2a: Single cavities

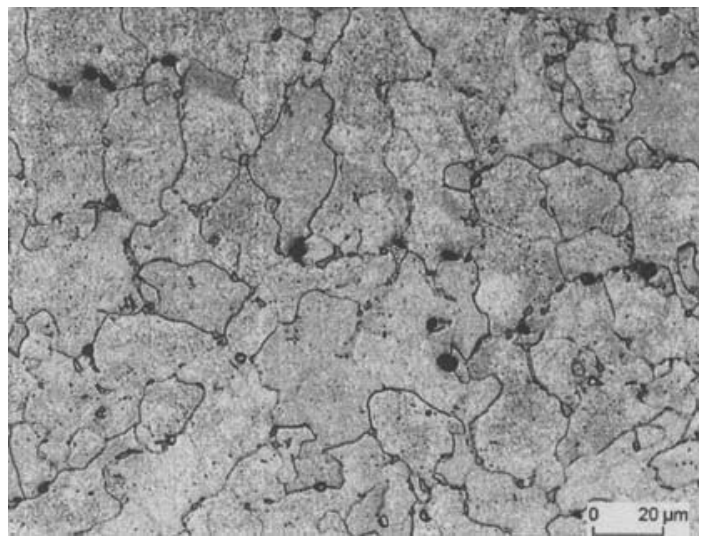

Assessment class 3a: Numerous oriented cavities

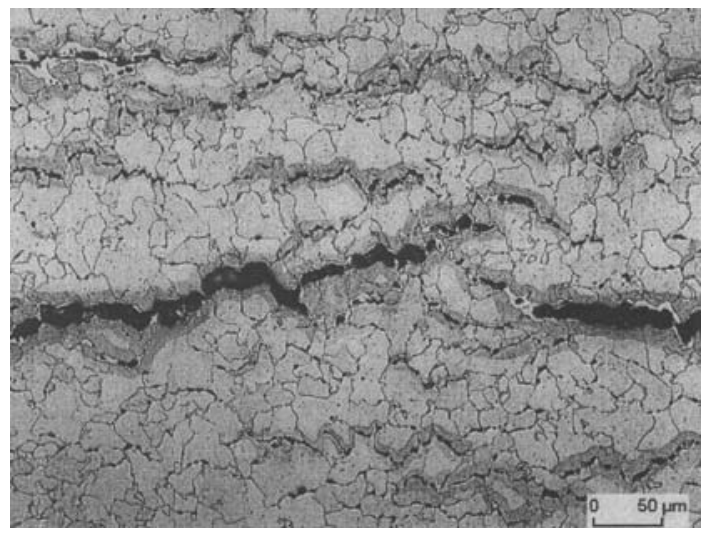

Assessment class 4: Creep microcracks

Figure 3: States of material 14MoV6-3 damage [8]

\section{Conclusion}

Our proposal for Czech power plants anticipates a shift in service life from grade $3 a$ to $3 b$, i.e. to allowed length of string cavitation $100 \mu \mathrm{m}$ at a density of 20 microcracks $/ \mathrm{mm}^{2}$ for steel 15128 or its international EN equivalents. The proposal is based on an experimental evaluation of microstructures, creep behavior and changes in wall thickness of bends and pipes at $6 \mathrm{CEZ}$ power plants operated for a period of 25 to 35 years.

Another topic for research is the design of checks on the service life of steam pipelines in the area of creep damage and damage assessment of the microstructures of grade 15 steels and the new class of T23, T24, P91, P92 and E911 steels. 


\section{References}

[1] Svobodová, M., Tůmová, D., Čmakal, J.: Dilčí odborná rešerše "Přehled materiálových vlastností oceli 15128 z databáze UJP PRAHA, a.s.". [Zpráva UJP 1450] UJP PRAHA, a.s., Praha : listopad 2011, $22 \mathrm{~s}$.

[2] Fossil Plant High-Energy Piping Damage: Theory and Practice, Volume 1: Piping Fundamentals. EPRI, Palo Alto, CA: 2007. 1012201.K.

[3] Mentl, V.: ז̌́zení životnosti parovodů $v$ energetice. [Technická zpráva - Rešerše č. 16/2011/ KMM] KMM FS ZČU v Plzni, Plzeň : listopad 2011, $239 \mathrm{~s}$.

[4] Hromchenko, F. A.: Životnost svarových spoju parovodi. Moskva : Mashinostrojenie, 2002, 246 s. ISBN 5217031263.
[5] Калигин, Р. Н.: Прогнозирование Остаточного Ресурса Длительно Експлуатируюшихся Сбарных Соединений Паропроводов в $У_{C \text { - }}$ ловиях Ползучести по Структурному Факто$p b$. Бсероссийский теплотехнический научно-исследовательскуй институт. Москва : 2008.

[6] Antikajp, P. A.: Metallovedenie. Moskva : Metalurgija, 1972, $183 \mathrm{~s}$.

[7] Изюмский, Н. А.: Повышение надежсности паровых котлов и паропроводов.

[8] VGB-TW 507 - Teil2/Part2 Richtreihen/Rating Charts, Januar 2005. 